\title{
Potential Development and Internationalization of City-Based Creative Industries in Indonesia: A Case Study of Maros Regency, Indonesia
}

\author{
Burhanuddin ${ }^{1}$, Aswin Baharuddin ${ }^{2}$, Darwis Beddu ${ }^{3}$ \\ \{boerhi76@gmail.com ${ }^{1}$, sawingbahar@gmail.com ${ }^{2}$, dbundhy@yahoo.com ${ }^{3}$ \} \\ Department of International Relation, Faculty of Social and Political Sciences, Universitas \\ Hasanuddin, Jl. Perintis Kemerdekaan KM 10, Makassar, Indonesia ${ }^{1,2,3}$
}

\begin{abstract}
This study aims to analyze the dynamics of the development of the creative industry in Indonesia. More specifically, this study analyzes the relationship between the development of creative industries globally and nationally with the dynamics of district and city level creative industries in Indonesia. In the context of this research, the case raised is the result of mapping the creative industry in Maros Regency as one of the buffer regions of the capital city of South Sulawesi. This study uses a mixed-method type with an emphasis on the actor approach. The data in this study were obtained through Observation, Questionnaire, Interview, and Document Review. This research found that First, the Actors of Maros Regency creative industries have been spread into various subsectors even though the most dominant is the culinary industry. Second, the subsector which has the potential to become the leading creative industry in Maros Regency is the Culinary, Film, Craft, Application and Photography sub-sectors. Third, Maros Regency Creative Industry makes local culture its trademark.
\end{abstract}

Keywords: Creative Industry, Local Government, Global Economy, Indonesia

\section{Introduction}

Globalization has brought significant changes to the study of International Relations. One of the impacts is the expansion of issues from state-centred issues and the threat to sovereignty to non-traditional issues, including economics, culture, and human rights. One of the issues raised was the dynamics of actors in responding to the phenomenon of economic globalization. Actors are required to adapt and anticipate changes in the direction of the global economy. In the current context, the issue in question is the phenomenon of the development of creative and digital industries.

Globally, the development of creative industries is experiencing rapid development after the global trade regime that affirmed Trade-Related Intellectual Property Rights (TRIPs) at the Uruguay Round in Punta del Este in 1994. The multilateral agreement was then affirmed at the level of national governments, including Indonesia. With the agreement of TRIPs, this creativity and science-based industry get legal protection for their intellectual property. This is what drives the development of creative industries in various countries. 
The term creative industries can be traced together with the development of the Frankfurt School in the 1930s and 1940s. At that time, this terminology had a negative connotation because it was considered as part of the commodification of culture and only benefited a few parties. However, this perspective experienced a significant change in the 1960s, and this culture-based industry began to make a positive contribution to cultural preservation as well as economically. The development of discourse and the concept of this creative industry then became increasingly popular when UNESCO actively campaigned for it as a more sustainable future economic model and could greatly contribute to efforts to improve public welfare at various levels, both urban and traditional areas.

In the past decade, the discourse on the development of the creative industry in Indonesia has escalated significantly. The topic of the creative industry became the centre of attention of various stakeholders, both government, business, and academics. In the field of study of International Political Economy, discourse related to the Creative Industries focuses a lot on the relationship between industry players and the government in the development of creative industries. This can be seen through the research of Beukelaer [1] and Potts \& Cunningham [2].

Stretching The development of the creative industry in Indonesia is quite impressive. Contributions to Gross Domestic Product were recorded at 7.1 per cent in the 2010-2014 period. Furthermore, the added value generated reached Rp. 716.7 trillion in 2014. In the same year, the growth of Indonesia's creative industry was at 5.81 per cent. Indonesia's creative industry sector was also able to absorb 12 million workers in 2014. The data showed an increase of 0.63 per cent from the previous year [3].

Specifically, the Indonesian government through the Creative Economy Agency (BEKRAF) defines the creative economy as follows; "The creative economy is the creation of added value based on ideas born from the creativity of human resources (creative people) and based on science, including cultural and technological heritage." For the Government of Indonesia the development of creative industries is important because it has the potential to bring economic, social and cultural benefits.

The development of the creative industry can be seen through the dynamics of the actors, processes and subsectors. Actors from creative industries include governments, communities, business people, and academics. The intended process consists of 5 stages namely creation, production, distribution, consumption, and conservation. while the creative industry subsector consists of 16 fields namely Applications and Games, Architecture, Interior Design, Visual Communication Design, Product Design, Fashion, Film/Animation/Video, Photography, Craft, Culinary, Music, Publishing, Advertising, Performing Arts, Fine Arts, Television/Radio [4]

Seeing the enormous potential of the creative industry, the Indonesian government gradually made policy and institutional adjustments. During the Susilo Bambang Yudhoyono government, the intention to develop the creative industry was done by creating a grand design of Indonesia's creative industry which was then under the Ministry of Tourism and Creative Economy. This was continued by the Joko Widodo Government with the Creative Economy Agency (BEKRAF) which was directly supervised by the President based on President Regulation $6 / 2015$. From the elaboration above, it appears that the Indonesian government is aggressively developing the creative industry. This research itself tries to trace the relationship between the development of creative industries globally and nationally with the dynamics of the district and city level creative industries in Indonesia. In the context of this research, the case raised is the result of mapping the creative industry in Maros Regency as one of the buffer regions of the capital city of South Sulawesi. 


\section{Research Method}

This research was conducted in Maros Regency, South Sulawesi. Maros is essential as a research location because Maros is a buffer zone of the capital of South Sulawesi Province, and similar research has not been conducted. The research will be carried out using proportionally the two main approaches in research, namely, qualitative and quantitative. Method This research will try to find data and information through questionnaires, written sources and interviews. The data will be analyzed by studying the context or social situation of the phenomenon so that it can explain and present the data needed in full [5].

This research uses an actor approach. The data in this study were obtained through Observation, Questionnaire, Interview, and Document Review. Initial observations were made to find the number of creative economic actors. Questionnaires were distributed to creative economic actors to obtain quantitative data. The sampling technique uses non-probability sampling with accidental and snowball methods. Interviews were conducted to obtain more indepth data from parties related to the topic of this study from the government, creative economy actors, consumers and communities supporting the running of the creative industries in Maros Regency. Document Review, the intended document is various data collected from journals, books, data from the internet and documents from parties related to this topic. The data that has been collected is then grouped and organized according to their patterns. This data will then be analyzed according to the planned framework and flow and research methods. In this study, data will be mapped about the context of the development of the creative industry in Maros Regency.

\section{Result and Discussion}

The creative industry is the relationship between creativity and economics values. Furthermore, the creative industry elaborates how they can be combined to create value and wealth [6]. Some recent research related to the creative industry has focused a lot on the role of the state and business people in creative industries in countries including Indonesia, which has been done by Hanan \& Hemanto [7]. In this research, it is explained how the efforts of the creative industry players in producing developing space for their business. Other research proposed by Purnomo \& Kristiansen [8] which explains how economic policy can encourage the development of creative industries.

In the subnational level, the leading research was carried out by Yum [9] This research focuses on the relationship between the creative industry and the urban economy in the United States. In line with the research, this article also discusses the dynamics of actors in developing creative industries at the district or city level. The difference is the location of the research and its national policy context. Discussions on the role of actors at the city level in the development of creative industries were also raised by the United Nations Development Program (UNDP). In its publication, UNDP mapped the successful practices of managing local creative industries in various countries, including Indonesia [10].

Massive opportunities arising from the development of the creative economy sector and large market niches both nationally and globally can be utilized by businesses in various Regions including Maros district. This type of business classification is based on 16 creative industry sub-sectors compiled by the Indonesian Creative Economy Agency. Our data shows that the culture-based Creative Industry of Maros Regency is still dominated by the culinary sector, which is about 85 per cent of the creative industries. Then, craft by $10 \%$, photography, 
film and animation by $4 \%$, and application development by $1 \%$. This data shows that Maros Regency Government still needs to boost and accelerate the development of other subsectors. From the mapping results above, the data are then analyzed to find sub-sectors and actors that have the potential to be excellent Maros Regency. The subsectors and actors are as follows;

First, the film subsector, as one of the national creative industry subsectors, the film sector continues to experience significant development. This development is supported by a huge number of Indonesian cinema viewers, making it a very potential market for the development of the entertainment industry such as film. The sizeable economic value of this industry has led to an increase in the number of production and actors that play a role in it. This is illustrated by the increase in the number of film production houses, both large-scale and independent initiatives. This phenomenon does not only occur in big cities like Jakarta, Surabaya, Bandung, Yogyakarta and Makassar, but the resonance has reached other cities or districts. In the context of South Sulawesi, Makassar as a centre for the growth of the creative industry in the film industry sub-sector in eastern Indonesia has spread its stretches to other districts/cities including Maros Regency. From digital search, the research team found several digital traces of short films by filmmakers in Maros Regency. The filmmaker in Maros Regency is dominated by young people despite having a background.

Some filmmakers who appear to colour the cinema universe in South Sulawesi include Cokko-Cokko Production with his work "Patah Hati Tanpa Batas in 2018", Akrab Arba Production with his work "Sahabat Pohon Kelapa in 2014", "Jangan Terlambat in 2016", and "Initial Syafirah in 2017. In addition to the two actors above, other potentials in the field of the film have also emerged among Maros Regency students. This can be seen through the competition held by the Lontara Cultural Arts Institute in 2017. The enthusiasm of students is quite large in participating in the competition. Another potential also emerged from the Maros Regency Village Youth Forum which initiated the making of a film titled "Battu Ritanayya in 2016" as a medium of creative campaigns to respond to the declining number of young people who wish to become farmers. From the works elaborated in the previous section, it appears that the hallmark of films by Maros filmmakers is to make stories, problems, wisdom and local culture as sources of their inspiration. The local cultural riches that they played on later became a differentiator or differentiation of Maros so that it was very likely to access national and Southeast Asian markets in the future. However, films by filmmakers must first obtain a place in their home regions. Seeing the stretching of filmmakers in the last three years, the potential of this subsector in the future has the potential to become superior in Maros Regency.

Second, Application Development, Nationally the development of the creative industries in the Application sub-sector, has become excellent, considering the growing number of smartphone users and electronic-based transactions. Forerunner to the development of the subsector in Maros Regency has the potential to start from an education-based non-profit community, namely the "Maros IT Community (KomIT). KomIT Maros is a community that brings together IT (Information And Technology) activists in Maros Regency to intensively carry out educational programs to the Maros community to increase the population of Information and Technology literacy. Now, this community has opened commissariat in several campuses located in Maros Regency. Although engaged in the knowledge sector, the existence of this organization is an essential factor in upgrading the creative subsector value chain in the field of application and the development of internet-based UMKM support systems.

Third, the Culinary Sector, In the culinary sector, Maros is an area with an abundance of culinary recipes. One that stands out is Roti Maros. Maros Bread is a typical culinary with the concept of bread filled with typical Maros Regency jams. This comestible is commonly found along the road when crossing Maros Regency. These Maros Bread traders began to increase 
dramatically in the late 1990s and became a unique ole-ole for the people of South Sulawesi who were active across the Maros Regency. After more than two decades, this culinary comestible is still in demand not only because of the unique taste but also because the price remains affordable. The next actor is the Rajungan Crab Processing Entrepreneur Group consisting of fishermen wives. This group was formed as a result of the OXFAM coastal community empowerment program through the Restoring Coastal Livelihood (RCL) program. Economically this program has been able to produce a sustainable and robust business institution.

Fourth, Craft Subsector, In the craft or craft sector, one of the crafts that stands out is the manufacture of merchandise from butterflies. Maros Regency has a geographical advantage as an area that is a growth space for butterflies. The main landmarks have become National Geopark Parks and have been registered with UNESCO. Thus Geopark will become a tourist destination and attract national and foreign tourists. An excellent tourist destination will stimulate other needs; namely, the creative industry supporting tourism, in this case, is the butterfly craft industry. Next up is the zither craft, this craft is quite unique and potentially very much needed in the future as the local culture-based arts industry develops. Even though the economic value is still limited at the moment, it has the potential to supply the handicraft industry.

Fifth, Photography. As in other big cities, the photography service industry stems from a hobby-based non-profit community. A similar thing happened in Maros Regency through the Maros Photography Community (Marfografi). Members of this community come from various backgrounds, ranging from civil servants to students. This hobby-based community helps forge its members to add and explore skills and techniques to get quality photography.

From the mapping results above, it appears that the types of creative industries that are developing nationally in Indonesia are in harmony with those running at the Maros district level. This can be seen through the types of potential creative industries including Culinary, Craft, Photography, Film / Animation and Application Development. Even though it is not as massive as the big cities in Indonesia, the potential of the Maros Regency Creative Industry shows promising potential if supported by favourable policies and creative industry ecosystems.

\section{Conclusion}

The findings of this study are as follows; First, Maros Regency creative industry actors have spread into various subsectors, although the most dominant is the culinary industry. Second, the Subsectors that have the potential to become the leading creative industries in Maros Regency are the Culinary, Film, Craft, Application and Photography fields. Third, Maros Regency Creative Industry makes local culture its trademark

\section{References}

[1] Beukelaer, C. D.: Creative industries in "developing” countries: Questioning country classifications in the UNCTAD creative economy reports, Cultural Trends, Vol. 23, no. 4, pp. 232-251 (2014) 
[2] Potts, J and Cunningham, S.: Four models of the creative industries, International Journal of Cultural Policy, International Journal of Cultural Policy, Vol. 14, no. 3, pp. 233-247 (2008)

[3] Badan Ekonomi Kreatif: Sistem Ekonomi Kreatif Nasional: Panduan Penilaian Mandiri Kabupaten/Kota kreatif, Jakarta, Bekraf pp. 3-4 (2016)

[4] Badan Ekonomi Kreatif :Sistem Ekonomi Kreatif Nasional: Panduan Penilaian Mandiri Kabupaten/Kota kreatif," Jakarta, Bekraf, pp. 14-32 (2016)

[5] Harison, L.: Metodologi Penelitian Ilmu Politik (terjemahan), Jakarta: Penerbit Kencana (2007)

[6] Howkins, J.: Creative Economy: How People Make Money from Ideas (second edition), Penguin Global Publisher (2001)

[7] Hanan, H and Hemanto, D.: From clothing to culinary industries: creativity in the making of place, Creative Industries Journal, pp. 1-20 (2019)

[8] Purnomo, B. R and Kristiansen, S.: Economic reasoning and creative industries progress, Creative Industries Journal, Vol. 11, no. 1, pp. 3-21 (2018)

[9] Yum, S.: The relationship between creative industries and the urban economy in the USA, Creative Industries Journal, pp. 1-22 (2019)

[10] UNDP: Creative Economy Report 2013 (Special Edition) widening local development pathways. United Nations Development Program, New York (2013)

Acknowledgement. We would like to thank the LPPM Hasanuddin University for funding this research. 